\title{
Penyusunan Portofolio Kampung Pendidikan Arek Surabaya
}

\author{
Yesa Cahayaning Ramadhani ${ }^{* 1}$, Asmara Indahingwati ${ }^{2}$ \\ 1,2Program Studi Manajemen, Sekolah Tinggi Ilmu Ekonomi Indonesia (STIESIA) Surabaya \\ *e-mail: yesacahayaning@stiesia.ac.id ${ }^{1}$, asmaraindahingwati@stiesia.ac.id ${ }^{2}$
}

\begin{abstract}
Parenting patterns depend on how a family environment forms rules that must be obeyed by family members. This parenting pattern is formed by parents consisting of fathers and mothers to provide education to their children so that it can imprint on the child and make characteristics and personal for the child. So the mayor of Surabaya held the Kampung'e Arek Suroboyo education village competition as one of the Surabaya City Government's programs in promoting the development of the quality of human resources (HR). So that it mandates "the community is obliged and responsible for the protection of children through the activities of the community's role in the implementation of child protection. The conclusion of this community service activity is the creation of this Education Village aims to create an environment that is educational, safe, comfortable, friendly, healthy, creative and literate for child growth and development process in community support that ensures the fulfillment of children's rights and strives for optimal child protection.

Keywords: Earning Village, Healthy Village, Foster Village, Healthy Village, Creative Village, Safe Village

Abstrak

Pola pengasuhan tergantung dari bagaimana suatu lingkungan keluarga membentuk aturan yang harus dipatuhi oleh anggota keluarganya. Pola pengasuhan ini dibentuk oleh orangtua yang terdiri dari ayah dan ibu untuk memberikan pendidikan pada anaknya sehingga dapat membekas pada diri anak dan menjadikan karakteristik dan pribadi bagi diri anak. Maka wali kota surabaya mengadakan lomba kampung pendidikan Kampung'e Arek Suroboyo merupakan salah satu program Pemkot Surabaya dalam menggenjot pengembangan kualitas sumber daya manusia (SDM). Sehingga mengamanatkan "masyarakat berkewajiban dan bertanggung jawab terhadap perlindungan anak melalui kegiatan peran masyarakat dalam penyelenggaraan perlindungan anakKesimpulan dari kegiatan pengabdian masyarakat ini adalah terciptanya Kampung Pendidikan ini bertujuan untuk menciptakan lingkungan daerah tinggal yang edukatif, aman, nyaman, ramah, sehat, kreatif dan literat bagi proses tumbuh kembang anak dalam dukungan masyarakat yang menjamin pemenuhan hak anak dan mengupayakan perlindungan anak secara optimal.
\end{abstract}

Kata kunci: Kampung Belajar, Kampung Sehat, Kampung Asuh, Kampung Sehat, Kampung Kreatif, Kampung Aman

\section{PENDAHULUAN}

Surabaya adalah kota terbesar dan tertua di Indonesia, dengan total luas 330,45 km2 dan jumlah penduduk lebih dari 3 juta orang di malam hari dan lebih dari 5 juta orang di jam kerja. Surabaya terletak di timur laut Pulau Jawa. Surabaya merupakan pelabuhan laut dengan Pelabuhan Tanjung Perak sebagai pelabuhan utama. Pelabuhan Tanjung Perak berfungsi sebagai hub / pusat untuk pengiriman antar pulau di wilayah Indonesia Timur.

Di era teknologi yang semakin maju, dimana masyarakat hidup modern, kepedulian masyarakat terhadap lingkungan semakin menipis. Banyak limbah tak terpakai yang terdapat di lingkungan masyarakat terbuang percuma tanpa adanya perhatian masyarakat untuk memanfaatkannya. Limbah yang dinilai tidak berguna dan merusak lingkungan, apabila diolah dan dikelola dengan lebih baik akan menjadi sesuatu yang bermanfaat dan berdampak positif. Pemanfatan limbah maupun barang tak pakai menjadi sesuatu yang memiki nilai jual sangat diperlukan untuk melestarikan lingkungan maupun menjadi penghasilan lebih.

Oleh sebab itu Wali kota surabaya mempunyai misi yaitu "Menuju surabaya lebih baik" adalah sebuah amanah. Sampai hari ini Kota Surabaya telah berevolusi menjadi pusat kegiatan ekonomi, politik, dan budaya yang senantiasa terus berusaha menjawab tuntutan serta tantangan zaman. "Menuju Surabaya Lebih Baik" identik dengan upaya untuk menjawabnya. Zaman adalah idiom terbaik untuk menggambarkan dinamika perubahan serta perkembangan 
aspirasi masyarakat. Artinya, tuntutan serta tantangan zaman adalah sama dan sebangun dengan perubahan serta perkembangan kebutuhan, keinginan, dan harapan masyarakat. Oleh sebab itu tak dapat dipungkiri bahwa "Menuju Surabaya Lebih Baik" adalah kristalisasi aspirasi sekaligus amanah rakyat. Seluruh warga Kota Surabaya jelas menghendakinya. Tugas dan kewajiban kita sekarang adalah berusaha sekuat tenaga, dengan memanfaatkan segala sumber daya yang ada, untuk mewujudkan kehendak tersebut.

Pengasuhan (parenting) membutuhkan sejumlah kemampuan interpersonal dan mempunyai tuntutan interpersonal yang besar, tetapi sangat sedikit dalam pendidikan formal mengenai tugas ini. Pola pengasuhan tergantung dari bagaimana suatu lingkungan keluarga membentuk aturan (perilaku, norma dan nilai) yang harus dipatuhi oleh anggota keluarganya. Pola pengasuhan ini dibentuk oleh orangtua yang terdiri dari ayah dan ibu untuk memberikan pendidikan pada anaknya sehingga dapat membekas pada diri anak dan menjadikan karakteristik dan pribadi bagi diri anak. Di masing-masing keluarga memiliki pola-pola pengasuhan yang berbeda, tergantung dari bagaimana pandangan orangtua dalam memberikan asuhan pada anak-anaknya (Santrock, 2011).

Maka untuk melaksanakan misi wali kota surabaya mengadakan lomba kampung pendidikan Kampung'e Arek Suroboyo merupakan salah satu program Pemkot Surabaya dalam menggenjot pengembangan kualitas sumber daya manusia (SDM). Salah satunya melalui pendidikan. Karena tercermin dalam Ratifikasi Konvensi Hak Anak dalam UU No. 23/2002 yang direvisi menjadi UU No. 35 tahun 2014 tentang Perubahan UU Perlindungan Anak, dan Perda No 6 Tahun 2011 mengamanatkan "masyarakat berkewajiban dan bertanggung jawab terhadap perlindungan anak melalui kegiatan peran masyarakat dalam penyelenggaraan perlindungan anak". Pentingnya pendidikan bagi anak usia dini telah menjadi perhatian para pakar pendidikan sejak lama terutama UNESCO memberikan empat alasan tentang pentingnya Pendidikan Anak Usia Dini (PAUD), yaitu: PAUD merupakan fondasi awal dalam meningkatkan kemampuan anak untuk menyelesaikan pendidikan yang lebih tinggi, menurunkan angka mengulang kelas dan angka putus sekolah dan merupakan hak setiap anak untuk memperoleh pendidikan yang dijamin oleh negara (Prasanti \& Fitriani, 2018)

Apalagi Surabaya telah empat kali berturut-turut meraih penghargaan Kota Layak Anak mulai 2011. Untuk memenuhi komitmen itu, Wali Kota Surabaya Tri Rismaharini meresmikan lomba kampung pendidikan Kampung'e Arek Suroboyo mulai tahun 2016 sampai sekarang tahun 2018. Dia mengimbau seluruh lurah dan camat menciptakan kondisi kampung yang nyaman. Terutama bagi tumbuh kembang dan pendidikan anak-anak. Bukan perlombaan atau hadiah yang dikejar. Namun, yang terpenting adalah terciptanya kondisi kampung yang kondusif. Terciptanya tujuan lingkungan daerah tinggal (kampung) yang edukatif, aman, nyaman, ramah, sehat, kreatif dan literat bagi proses tumbuh kembang anak dalam dukungan masyarakat yang menjamin pemenuhan hak anak dan mengupayakan perlindungan anak secara optimal.

Maka Para Lurah sangat support dalam program ini. Sehingga dapat menginisiatori warga untuk ikut serta dalam melaksanakan program tersebut. Untuk hasil akhir berupa kekalahan atau kemenangan adalah Tidak ada masalah yang penting adalah usaha dalam melaksanakan program tersebut dengan baik.

Masing - masing kampung dapat bebas berkreasi dalam menciptakan kondisi belajar yang nyaman. Bisa berupa pendirian pojok membaca maupun pengaturan jam belajar untuk warga. Suasana belajar yang nyaman dan kondusif dapat diciptakan untuk menarik antusiasme warga untuk belajar.

Tahun ini sasaran program kampung pendidikan adalah Penekanan pada pemberdayaan masyarakat peduli pengasuhan anak dan BUKAN pada LOMBA semata tetapi pada penajaman dan penambahan indikator yang merujuk terwujudnya Kota Layak Anak dan permasalahan aktual dan Pemerataan ke semua wilayah kecamatan di Surabaya. Sehingga para warga bisa diharapkan menjadi pilot project di setiap kelurahan. Ruang lingkup kampung pendidikan 
Kampung'e Arek Suroboyo secara administrasi meliputi satu RW. Bisa terdiri atas gabungan beberapa RT yang memiliki delapan kategori dalam program itu. Yakni, kampung belajar, kampung sehat, kampung asuh, kampung kreatif dan inovatif, serta kampung aman. Dalam pengabdian ini berada di wilayah Kecamatan Rungkut memiliki luas kurang lebih 258,43 Ha dengan jumlah jiwa 21,08 juta dimana terletak didaerah perkampungan dengan batas-batas sebagai berikut:

1. Kel. Rungkut Kidul : 1.37 Jiwa

2. Kel. Medokan Ayu : 7.23 Jiwa

3. Kel. Wonorejo : 6.48 Jiwa

4. Kel. Penjaringan Sari : 1.81 Jiwa

5. Kel. Kedung Baruk : 1.55 Jiwa

6. Kel. Kali Rungkut : 2.58 Jiwa

Pada tahun ini yang mewakili mengikuti lomba KP KAS 2018 untuk kategori kampung binaan dari RW 05 adalah Wilayah RW 14 Kelurahan Kalirungkut Kecamatan Rungkut Surabaya. Dengan mengikuti lomba KP KAS, wilayah RW 14 berusaha berpacu menuju kampung yang setara dengan kampung yang sudah maju di wilayah Surabaya. Tujuan Mengikuti lomba KAMPUNG PENDIDIKAN KAMPUNGE AREK SUROBOYO yang merupakan program pemerintah kota Surabaya tahun 2018 sebagai berikut: Terciptanya Kampung Belajar, Kampung Sehat, Kampung Asuh, Kampung Sehat, Kampung Kreatif, Kampung Aman, Kampung Literasi dan Kampung Binaan.

Adapun untuk menunjang kegiatan ini kita perlu membangun dari:

$>$ Keluarga $\rightarrow$ Peduli Anak

$>$ Kampung $\rightarrow$ Ramah Anak: belajar, asuh, aman, sehat, dan kreatif

$>$ Kota $\rightarrow$ Surabaya Layak Anak

$>$ Negara $\rightarrow$ NKRI Yang bersatu: sejahtera adil dan makmur

Tujuan Umum Menciptakan kondisi daerah tinggal (kampung) yang aman dan aman bagi proses tumbuh kembang anak dalam dukungan masyarakat yang menjamin pemenuhan hak anak dan mengupayakan perlindungan anak secara optimal. Kondisi Wilayah RW 14 terdiri dari 4 RT. Sumber daya manusia jumlah penduduk KK $7.124=22.474$ jiwa terdiri dari 15 RW 86 RT.

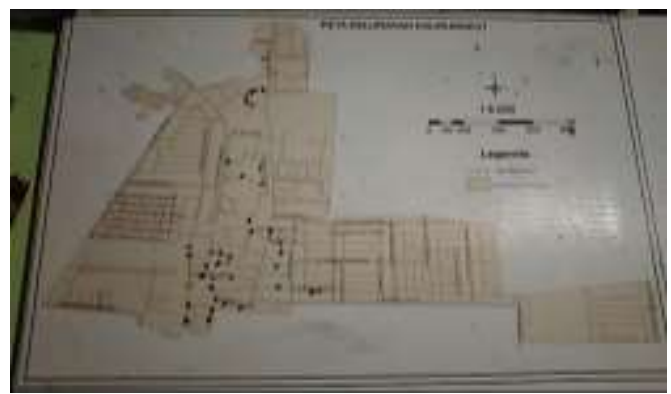

Gambar 1. Denah Lokasi Wilayah Kecamatan Rungkut

\section{METODE}

Bentuk kegiatan berupa Penyusunan Portofolio Kampung Pendidikan Arek Surabaya. Untuk lebih memahami kebutuhan dari masyarakat sasar, di awal dilakukan metode ceramah, pembimbingan penyusunan media diskusi dan Tanya jawab. Penyusunan Portofolio merupakan salah satu manajemen yang berhubungan dengan Ada organisasi yang bersifat bisnis (mencari keuntungan), seperti perusahaan-perusahaan. Ada organisasiyang mendorong kegiatan sosial, seperti perkumpulan arisan, kepengurusan RT (rumah tangga) dan RW (rumah warga), bahkan ada organisasi yang bertujuan mengoordinasi negara-negara didunia, yaitu PBB (Perserikatan Bangsa-Bangsa). Organisasi tersebut didirikan untuk mencapai tujuan tertentu, baik tujuan 
profit (memperoleh keuntungan) maupun tujuan nonprofit (bukan untuk memperoleh keuntungan). Apa yang dimaksud dengan terkoordinasi? Dua orang yang bekerja sama tentunya memerlukan koordinasi. Misalnya, dalam kegiatan sosial, Andamelakukan pembagian kerja. Teman Anda mengerjakan dekorasi panggung, sedangkanAnda menjemput artis penyanyi. Apa yang dimaksud dengan terstruktur? Organisasi militer merupakan contoh organisasi yang mempunyai struktur yang ketat. Sebaliknya, kegiatan RT (rumah tangga) atau RW (rukun warga) merupakan contoh organisasi yang mempunyai struktur yang longgar. Organisasi militer mempunyai deskripsi pekerjaan yang jelas, atasan yang jelas, aturan yang jelas, dan mengikat. Sebaliknya, RT atau RW, meskipun ada Pak RT ataupun Pak RW, strukturnya tidak begitu ketat dan peraturan tidak sama mengikatnya dibandingkan dengan organisasi militer (Hanafi, 2008). Pemecahan Masalah dan Pelaksanaan Kegiatan adalah sebagai berikut:

a. Kerangka Pemecahan Masalah

Untuk memecahkan permasalahan tersebut perlu diadakan pengabdian kepada masyarakat untuk Penyusunan Portofolio Kampung Pendidikan Tahun 2017 dengan langkah-langkah sebagai berikut :

1. Memberikan ceramah mengenai program kampung belajar, kampung sehat, kampung kreatif, kampung aman dan kampung asuh

2. Membimbing warga untuk menyusun materi portofolio dengan menggunakan media diskusi dan Tanya jawab.

b. Realisasi pemecahan masalah

Untuk memecahkan permasalahan di atas maka akan dilakukan pelatihan penggunaan media diskusi dan Tanya jawab pada Penyusunan Portofolio Kampung Pendidikan Tahun 2017.

c. Khalayak Sasaran

Kegiatan Pengabdian pada masyarakat ini melibatkan 1 RW yang terdiri dari 2 RT

d. Keterkaitan Kegiatan

Kegiatan pengabdian kepada masyarakat ini melibatkan 1 RW yang terdiri dari 2 RT, melalui pelatihan ini diharapkan para warga menjadi lebih kreatif dalam menyusun portofolio dengan menggunakan media diskusi serta dapat menerapkannya dalam proses Tanya jawab.

e. Evaluasi

Evaluasi dilaksanakan di akhir kegiatan dengan cara meminta kepada para peserta pelatihan untuk mengungkapkan kritik dan saran setelah mengikuti kegiatan pelatihan ini dan juga mengoreksi kekeliruan tugas warga dalam menyusun portofolio dengan menggunakan media diskusi dan Tanya jawab

\section{HASIL DAN PEMBAHASAN}

Program kegiatan pengabdian pelatihan penyusunan portofolio kampung pendidikan dengan media diskusi dan tanya jawab telah dilaksanakan $1 \mathrm{RW}$ yang terdiri dari 2 RT yaitu RW 05, RT 04 dan RT 06 bertujuan untuk mendidik anak - anak dan keluarga yang disebabkan lingkungan disekitar akan memacu kenyamanan dan perlindungan anak - anak (Arisanti, 2020). Pada saat kegiatan pengabdian para warga kalirungkut sangat antusias dan bersemangat mengikuti kegiatan pengabdian ini karena bagi mereka ini merupakan materi yang menarik dan sangat bermanfaat untuk diterapkan pada proses terciptanya tujuan lingkungan daerah tinggal bernuansa kampung yang edukatif, aman, nyaman, ramah, sehat, kreatif dan literat bagi proses tumbuh kembang anak dalam dukungan masyarakat yang menjamin pemenuhan hak anak dan mengupayakan perlindungan anak secara optimal. Hasil ini terlihat dari mereka mampu menyusun program kampung belajar, kampung sehat, kampung kreatif, kampung aman dan kampung asuh dengan menggunakan media diskusi dan tanya jawab. Pada beberapa program yang akan diprogram lebih banyak menekankan tentang teori atau konsep, media diskusi dan tanya jawab sangat membantu para warga dalam mempersiapkan materi yang akan mereka ajar, mereka berpendapat bahwa dengan menyampaikan materi pelajaran dengan menggunakan media permainan edukatif seperti teka teki silang dan acak kata ini maka peserta didik atau 
siswa akan merasa tertarik dan lebih bisa mengeksplorasi konsep konsep konsep yang mereka miliki.

\section{- Kampung belajar}

1. Pendidikan Anak Usia Dini

Anak usia dini dapat didefinisikan sebagai anak di umur lima hingga empat belas tahun. Sementara itu, Phillips et al (2010) menggolongkan anak usia dini ke dalam empat kelompok, yaitu: yaitu beginner (5-9), elementary (11-13), lower-intermediate (8-13), dan intermediate (12-14). Pada tingkatan intermediate, anak bermain berdasarkan imaginasinya sebagai contoh fantasy island. Selain itu, anak di umur tujuh sampai dua belas tahun berkembang sebagai pemikir, sudah dapat membedakan antara sesuatu yang nyata dan imaginasi (Phillips, Burwood, Dunford, \& Maley, 2000).

Pendidikan Anak Usia Dini (PAUD) dengan nama "Rahmatullah". Salah satu kegiatan pendidikan di wilayah RW 14 yaitu Pendidikan Anak Usia Dini (PAUD) dengan nama "Rahmatullah" bertempat di Jalan Rungkut Lor VII No. 23 setara dengan Taman Kanak - Kanak (TK). Dengan pelaksanaan kegiatan :

a. TK A (Hari Senin - Sabtu: Pukul 07.00 - 09.30 WIB)

Kelompok TK A siswanya berusia 4 tahun dengan jumlah anak didik 38 anak.

b. TK B (Hari Senin - Sabtu: Pukul 09.30 - 12.00 WIB)

Kelompok TK B siswanya berusia 5 tahun dengan jumlah anak didik 31 anak.

SK No : 101235780034

Penanggung Jawab: RA - Kemenag

Kepala sekolah : Bu Nur Laili

Pendidik

:

1. Guru kelas A1: Bu Mustoinah

2. Guru kelas A2: Bu Aini

3. Guru kelas B1: Bu Diah

4. Guru kelas B2: Bu Lin

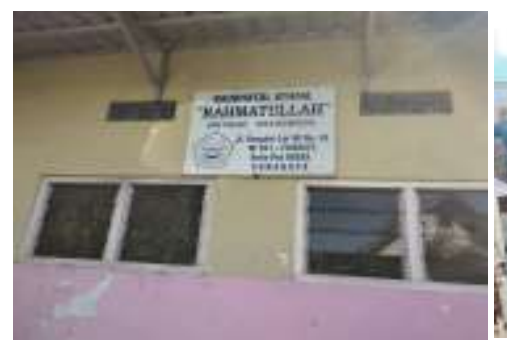

(a)

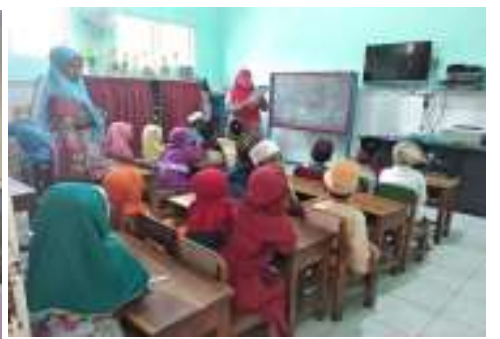

(b)

Gambar 2. Tempat Belajar (a) Lokasi belajar (b) Proses belajar

\section{Taman Bacaan Masyarakat (TBM) Sakura}

Pada mulanya program TBM yang mulai muncul sejak tahun 1992/1993 merupakan pembaharuan dari Taman Pustaka Rakyat (TPR) yang didirikan oleh Pendidikan Masyarakat pada tahun 1950-an. Program TBM ini bertujuan untuk meningkatkan minat baca dan budaya baca masyarakat. Kemudian semakin berkembang pesat setelah munculnya UU RI No 20 Tahun 2003 tentang Sistem Pendidikan Nasional, pasal 26 ayat (4), disebukan bahwa satuan pendidikan nonformal terdiri atas lembaga kursus, lembaga pelatihan, kelompok belajar, pusat kegiatan belajar masyarakat, majelis taklim, serta satuan pendidikan yang sejenis.

Kemuculan Taman Bacaan Masyarakat (TBM) menjadi embrio pendidikan alternative (baca: informal dan nonformal) untuk mendorong Gerakan Membaca masyarakat secara swadaya. Seiring dengan adanya dukungan dari pemerintah terhadap berbagai TBM yang ada, muncul juga nama nama alternatif yang menggeser istilah perpustakaan. Dari berbagai yang 
muncul tersebut, sebut saja ada Pustaka Bergerak, Rumah Baca, Rumah Buku, Cafe Buku, Sanggar Baca, Kampung Baca dan sebagainya.

Dengan beragamnya kemunculan TBM tersebut, masyarakat kini lebih mudah untuk membaca buku sambil santai, bercanda dan dengan gaya yang "senyamannya". Disini orang bisa membaca buku sambil berdiskusi dan berbagi ide dengan terbuka. Pada prinsipnya TBM dirancang untuk memenuhi kebutuhan kreasi dan rekreasi masyarakat. Kreasi berarti TBM tidak hanya menyediakan buku buku saja, namun menciptakan aktivitas kreatif yang melibatkan partisipasi dari pengunjungnya. Sementara rekreasi berarti TBM harus menghindari nuansa kekakuan dan kesunyian, namun lebih kepada menciptakan suasana senang. TBM di wilayah RW 14, RT 03 berlokasi di kelurahan Kalirungkut Kecamatan Rungkut Surabaya, dimana TBM tersebut satu lokasi dengan BKB dan PPT Sakura.

1) Bina Keluarga Balita ( BKB ) dan PPT (Pos PAUD Terpadu) Sakura
Pelindung
: Lurah Kalirungkut
Penanggung Jawab :TP.PKK Kelurahan Kalirungkut
Pembina
Ketua
: PLKB dan POKJA 2
Wakil Ketua
: Fatlakah
Sekretaris
Yatmini
Bendahara
: Nurul Hidayati
Pendamping
: Utami dan Lilik Suwarni
BKB
: Katmi, Sri Sukarti dam Sri Murniati
: Nur Qomariah

2) Jam Operasional Warnet: Wilayah RW 14 tidak menerapkan pembatasan jam operasional warnet bagi anak - anak karena diwilayah tersebut tidak ada warga yang membuka jasa warnet.

3) Bebas anak putus sekolah: Pada wilayah RW 14 tidak ditemui anak putus sekolah. Semua anak usia produktif sekolah menempuh pendidikan sesuai dengan jenjang pendidikan masing-masing. Keadaan ini menjadi nilai baik kampung dan lingkungan, serta memberikan pengaruh positif karena setiap anak akan berinteraksi dengan anak yang memilki latar belakang pendidikan pula. Hal ini menjadikan perkembangan psikologis anak juga baik.

4) TPQ dan TK Assakinah: Taman pendidikan agama ini bertempat di Rungkut Lor VII No 28 Surabaya dengan jumlah santri sampai 40 anak lebih, adapun pelaksananya adalah setiap hari dari mulai pukul 15.00 - 17.00 WIB dan 18.00 - 20.00.

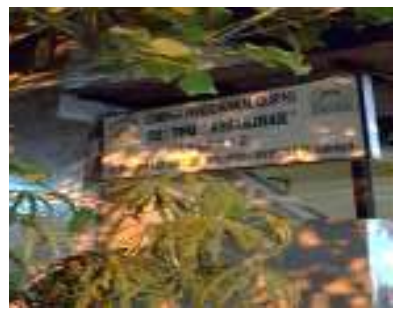

(a)

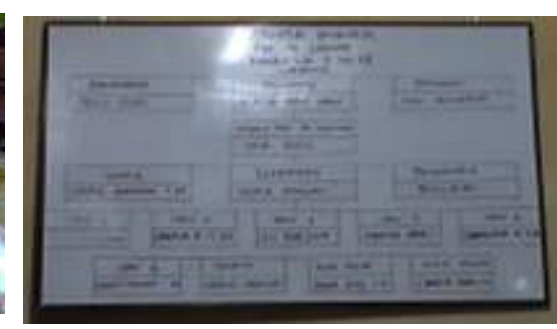

(b)

Gambar 3. TPQ dan TK Assakinah (a) Lokasi TPQ dan TK Assakinah

(b) Struktur pengurus TPQ "Assakinah"

\section{- Kampung Asuh}

Bina Bina Keluarga Balita ( BKB ) dan PPT Sakura terletak di RW 14 dan RT 01 dimana program Bina Keluarga Balita (BKB) menjadi salah satu program Badan Kependudukan dan Keluarga Berencana Nasional (BKKBN) untuk membantu meningkatkan pengetahuan dan keterampilan orang tua dan anggota keluarga lain dalam pembinaan tumbuh kembang anak yang dilakukan semenjak anak dalam kandungan sebagai upaya mewujudkan sumber daya manusia yang berkualitas. Kegiatan ini dilakukan dalam bentuk pos pelayanan terpadu (posyandu), bina keluarga balita (BKB), pendidikan anak usia dini (PAUD) yang pelayanannya dilaksanakan secara holistis integratif. Keluarga merupakan lingkungan pertama dan utama 
dalam memberi pembinaan tumbuh kembang, menanamkan nilai-nilai moral, menanamkan 8 fungsi keluarga \& pembentukan kepribadian yang mempunyai peranan penting dalam memenuhi kebutuhan hak-hak anak yaitu Asah, Asih, dan Asuh".

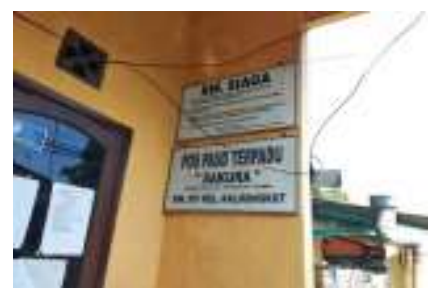

(a)

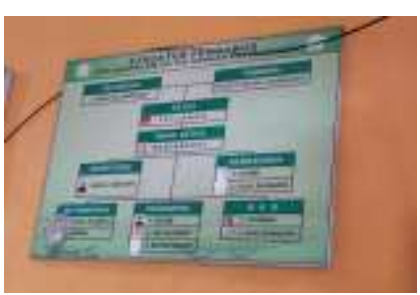

(b)

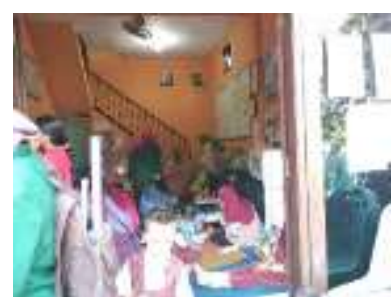

(c)

Gambar 4. Kampung asuh (a) Pos PAUD Terpadu Sakura (b) Struktur Pengurus PPT Sakura

(c) Aktivitas anak dan ibu di PPT dan BKB Sakura

\section{- Kampung Sehat}

Upaya pemerintah melalui program-program pembangunan yang telah dilakukan diantaranya meningkatkan akses masyarakat terhadap fasilitas kesehatan dan meningkatkan pelayanan kesehatan bermutu dan berkualitas, merata serta terjangkau, yaitu dengan memberikan pelayanan kesehatan gratis bagi penduduk miskin ; menyediakan sumber daya kesehatan yang kompeten dan mendistribusikan tenaga kesehatan secara merata ke seluruh wilayah, meningkatkan sarana dan prasarana kesehatan melalui pembangunan puskesmas, rumah sakit, polindes, posyandu serta menyediakan obat-obatan yang terjangkau oleh masyarakat Semua kampung tentu memiliki banyak keinginan yang terbaik dalam pencapain tujuan bersama, keinginan atas tujuan untuk menjadi kampung yang berkemajuan, tentu menjadi dambaan tiap lapisan warga dalam sebuah lingkungan wilayah RT atau RW. Kampung yang baik adalah kampung yang dapat memenuhi beberapa syarat dari berbagai aspek internal maupun eksternal. Satu wilayah kampung yang di koordinasi setingkat RT dan RW pasti banyak melakukan usaha-usaha demi mewujudkannya dan dapat melakukan persaian kompetisi antar kampung (Permata Sakti, 2017).

Program peningkatan perilaku hidup bersih dan sehat (PHBS) ini merupakan program nasional, yang dibuat untukseluruh wilayah di Indonesia. Dengan demikian, program-program yang terdapat dalam program PHBS tidak membuat perbedaan indikator penilaian untuk wilayah atau kawasan tertentu, seperti wilayah pantai, wilayah desa atau wilayah kota. Dengan demikian dalam pelaksanaan program PHBS di seluruh kawasan Indonesia juga menggunakan 10 indikator PHBS yang harus diperaktikan dirumah tangga karena dianggap mewakili atau dapat mencerminkan keseluruhan perliku hidup bersih dan sehat, indikator tersebut adalah: 1 . Pertolongan persalinan oleh tenaga kesehatan. 2. Bayi di beri ASI ekslusif. 3. Menimbang balita setiap bulan. 4. Ketersediaan air bersih. 5. Ketersediaan jamban sehat. 6. Memberantas jentik nyamuk. 7. Mencuci tangan dengan air bersih dan sabun. 8. Tidakmerokok dalam rumah. 9. Melakukan aktifitas fisik setiap hari. 10. Makan buah dan sayur (Ningsih \& Jonyanis, 2014).

Kampung sehat RW 14, RT 03 memiliki beberapa pencananan kegiatan yang telah dilaksanakan selama ini, dan akhirnya masuk ke dalam syarat kampung sehat. Berikut ini adalah pelaksanakan kegiatan yang termasuk dalam agenda kampung sehat

1. Ruang Bebas Asap Rokok: Menuju wilayah menjadi kampung sehat, wilayah RW 14, RT 03 sangat memperhatikan juga kualitas udara segar yang dikonsumsi warga terutama anakanak. Dalam masa pertumbuhannya anak-anak tentu memilki hak mendapat kualitas kesehatan yang baik, dengan adanya kegiatan bebas asap rokok warga dapat lebih mengontrol perilaku merokok bagi bapak-bapak dan kaum laki laki dewasa di wilayah RW 14, RT 03.

2. Bebas Miras dan Narkoba: Pemuda menjadi poros penting bagi lini kehidupan, selain sebagai penerus juga sebagai tolak ukur kualitas dan keberlangsungan kehidupan, seperti halnya pada RW 14, RT 03. Pemuda RW 14 RT 03 tidak tergolong sebagai sekelompok pecandu 
miras dan narkotika, hal ini tentu sangat memberikan nilai positif. Miras dan narkotika adalah musuh utama pemuda, dan pada wilayah ini tidak ada penyalahgunaan barang terlarang tersebut.

3. Layanan Kesehatan Masyarakat: Layanan kesehatan masyarakat di wilayah RW 14, RT 03 terdiri dari beberapa kegiatan kesehatan yang telah berlangsung, seperti posyandu balita, senam lansia, bumantik dan budaya gemar cuci tangan. Layangan kesehatan ini dilakukan secara terstuktur dan mengikat satu sama lain, untuk pemaksimalan kinerja dari kader kader kesehatan di lingkungan kampung.

Posyandu Sakura 2 sebagai salah satu wadah di wilayah RT 03 RW 14 untuk memantau pertumbuhan balita secara optimal ,agar menjadikan anak yang sehat dan berkualitas. Karena anak merupakan harapan masa depan keluarga dan bangsa.

1. Posyandu Sakura 2

Sasaran Posyandu Sakura 2

Semua warga yang ada diwilayah Posyandu Sakura 2 ,maupun diluar wilayah terdekat yang terdiri darl :

a. Bayi (usia 0 - 12 bulan)

b. Anak Balita (13 - 60 bulan)

c. Ibu Hamil ,lbu Melahirkan ,lbu Nifas dan Menyusui

d. Pasangan Usia Subur (PUS)

Tujuan Posyandu Sakura

Tujuan pelaksanaan kegiatan ini adalah: Memelihara dan meningkatkan kesehatan bayi ,balita ,ibu dan Pasangan usia subur . Dengan adanya posyandu ,bisa di deteksi Secara dini gangguan dan pertumbuhan pada bayi.

Manfaat Posyandu Sakura

1. Meningkatkan pencapaian ketrampilan kader secara maksimal dan berkelanjutan

2. Menciptakan kinerja dan kapasitas kader secara mandiri.

3. Mampu mengembangkan kreatifitas dan membangun relasi kader, baik didalam maupun diluar wilayah kerja .

4. Tumbuh Kembang anak bisa terdeteksi sejak dini .

Visi Dan Misi Posyandu Sakura

Visi : Mewujudkan anak yang sehat, cerdas dan berkualitas, Mengembangkan akses layanan kesehatan balita melalul Posyandu .

Misi : Sebagai model percontohan dengan Iingkungan bersih ,hjau ,sehat dan inovatif. Melayani dengan sepenuh hati ,3 S (Senyum ,Sapa ,Sabar)

Pelaksana Posyandu Sakura

Pelaksana harian posyandu adalah kader posyandu, baik itu laki-laki atau perempuan. Asalkan bisa membaca dan menulis, kerja ikhlas, mampu, dan mempunyai waktu luang.

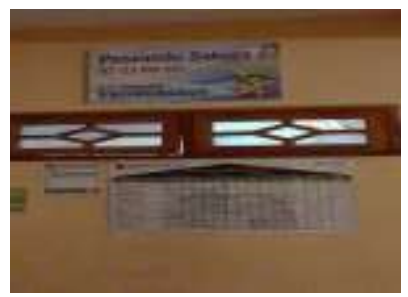

(a)

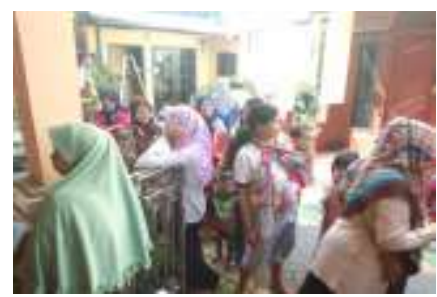

(b)

Gambar 5. Posyandu (a) Posyandu Sakura 2 RW 14, RT 03

(b) Kegiatan Posyandu 


\section{Posyandu Lansia Sakura}

Gizi adalah suatu proses organisme menggunakan makanan yang dikonsumsi secara normal melalui proses degesti, absorpsi, transportasi. Penyimpanan, metabolisme dan pengeluaran zat yang tidak digunakan untuk mempertahankan kehidupan, pertumbuhan, dan fungsi normal dari organ-organ serta menghasilkan energi. Menurut (Almatsier, 2009) zat-zat gizi yang dapat memberikan energi adalah karbohidrat, lemak, dan protein, oksidasi zat-zat gizi ini menghasilkan energi yang diperlukan tubuh untuk melakukan kegiatan atau aktivitas. Ketiga zat gizi termasuk zat organik yang mengandung karbon yang dapat dibakar, jumlah zat gizi yang paling banyak terdapat dalam pangan dan disebut juga zat pembakar (Almatsier, 2011) dan (Supriasa, 2012).

Posyandu lansia merupakan suatu fasilitas pelayanan kesehatan yang berada di desadesa yang bertujuan untuk meningkatkan kesehatan masyarakat khususnya bagi warga yang sudah berusia lanjut. Manfaat yang dirasakan dengan adanya posyandu lansia ini bukan hanya dirasakan oleh lansia tetapi juga oleh keluarga dan lingkungan dimana lansia tersebut tinggal. Posyandu lansia dapat membantu lansia untuk menyesuaikan diri dalam perubahan fase kehidupannya sehingga menjadi pribadi yang mandiri sesuai dengan keberadaannya.

Masalah Kesehatan pada Lansia

Masalah kesehatan pada lansia tentu saja berbeda dengan jenjang umur yang lain karena penyakit pada lansia merupakan gabungan dari kelainan-kelainan yang timbul akibat penyakit dan proses menua yaitu proses menghilangnya secara perlahan-lahan kemampuan jaringan untuk memperbaiki diri atau mengganti sel serta mempertahankan struktur dan fungsi normalnya, sehingga tidak dapat bertahan terhadap infeksi dan memperbaiki kerusakan yang diderita, masalah kesehatan pada lansia, yaitu:

1. Immobility (kurang bergerak), dimana meliputi gangguan fisik, jiwa dan faktor lingkungan sehingga dapat menyebabkan lansia kurang bergerak. Keadaan ini dapat disebabkan oleh gangguan tulang, sendi dan otot, gangguan saraf dan penyakit jantung.

2. Instability (tidak stabil/ mudah jatuh), dapat disebabkan oleh faktor intrinsik (yang berkaitan dengan tubuh penderita), baik karena proses menua, penyakit maupun ekstrinsik (yang berasal dari luar tubuh) seperti obat-obatan tertentu dan faktor lingkungan. Akibatnya akan timbul rasa sakit, cedera, patah tulang yang akan membatasi pergerakan. Keadaan ini akan menyebabkan gangguan psikologik berupa hilangnya harga diri dan perasaan takut akan terjadi.

3. Incontinence (buang air) yaitu keluarnya air seni tanpa disadari dan frekuensinya sering. Meskipun keadaan ini normal pada lansia tetapi sebenarnya tidak dikehendaki oleh lansia dan keluarganya. Hal ini akan membuat lansia mengurangi minum untuk mengurangi keluhan tersebut, sehingga dapat menyebabkan kekurangan cairan.

4. Intellectual Impairment (gangguan intelektual/ dementia), merupakan kumpulan gejala klinik yang meliputi gangguan fungsi intelektual dan ingatan yang cukup berat sehingga menyebabkan terganggunya aktivitas kehidupan sehari-hari.

5. Infection (infeksi), merupakan salah satu masalah kesehatan yang penting pada lansia, karena sering didapati juga dengan gejala tidak khas bahkan asimtomatik yang menyebabkan keterlambatan diagnosis dan pengobatan.

6. Impairment of vision and hearing, taste, smell, communication, convalencence, skin integrity (gangguan panca indera, komunikasi, penyembuhan dan kulit), merupakan akibat dari proses menua dimana semua panca indera berkurang fungsinya, demikian juga pada otak, saraf dan otot-otot yang dipergunakan untuk berbicara, sedangkan kulit menjadi lebih kering, rapuh dan mudah rusak dengan trauma yang minimal.

7. Impaction (konstipasi=sulit buang air besar), sebagai akibat dari kurangnya gerakan, makanan yang kurang mengandung serat, kurang minum, dan lainnya.

8. Isolation (depresi), akibat perubahan sosial, bertambahnya penyakit dan berkurangnya kemandirian sosial. Pada lansia, depresi yang muncul adalah depresi yang terselubung, 
dimana yang menonjol hanya gangguan fisik saja seperti sakit kepala, jantung berdebardebar, nyeri pinggang, gangguan pecernaan, dan lain-lain.

9. Inanition (kurang gizi), dapat disebabkan karena perubahan lingkungan maupun kondisi kesehatan. Faktor lingkungan dapat berupa ketidaktahuan untuk memilih makanan yang bergizi, isolasi sosial (terasing dari masyarakat), terutama karena kemiskinan, gangguan panca indera; sedangkan faktor kesehatan berupa penyakit fisik, mental, gangguan tidur, obat-obatan, dan lainnya.

10. Impecunity (tidak punya uang), semakin bertambahnya usia, maka kemampuan tubuh untuk menyelesaikan suatu pekerjaan akan semaki berkurang, sehingga jika tidak dapat bekerja maka tidak akan mempunyai penghasilan.

11. Iatrogenesis (penyakit akibat obat-obatan), sering dijumpai pada lansia yang mempunyai riwayat penyakit dan membutuhkan pengobatan dalam waktu yang lama, jika tanpa pengawasan dokter maka akan menyebabkan timbulnya penyakit akibat obat-obatan.

12. Insomnia (gangguan tidur), sering dilaporkan oleh lansia, dimana mereka mengalami sulit untukmasuk dalam proses tidur, tidur tidak nyenyak dan mudah terbangun, tidur dengan banyak mimpi, jika terbangun susah tidur kembali, terbangun didini hari-lesu setelah bangun di pagi hari.

13. Immune deficiency (daya tahan tubuh menurun), merupakan salah satu akibat dari prose menua, meskipun terkadang dapat pula sebagai akibat dari penyakit menahun, kurang gizi dan lainnya.

14. Impotence (impotensi), merupakan ketidakmampuan untuk mencapai dan atau mempertahankan ereksi yang cukup untuk melakukan senggama yang memuaskan yang terjadi paling sedikit 3 (tiga) bulan. Hal ini disebabkan karena terjadi hambatan aliran darah ke dalam alat kelamin sebagai adanya kekakuan pada dinding pembuluh darah, baik karena proses menua atau penyakit.

Data penyakit lansia di Indonesia (umumnya pada lansia berusia lebih dari 55 tahun) adalah sebagai berikut:

1. Penyakit Cardiovascular

2. Penyakit otot dan persendian

3. Bronchitis, asma dan penyakit respirasi lainnya

4. Penyakit pada mulut, gigi dan saluran cerna

5. Penyakit syaraf

6. Infeksi kulit

7. Malaria

8. Lain-lain

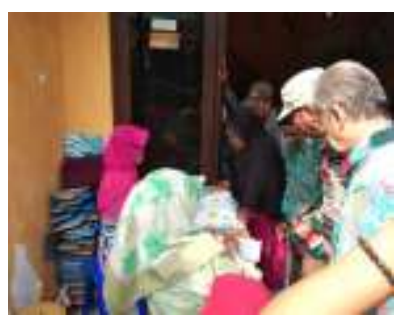

(a)

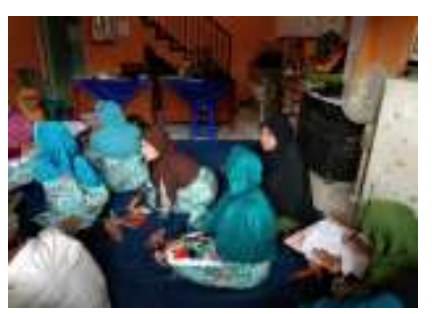

(b)

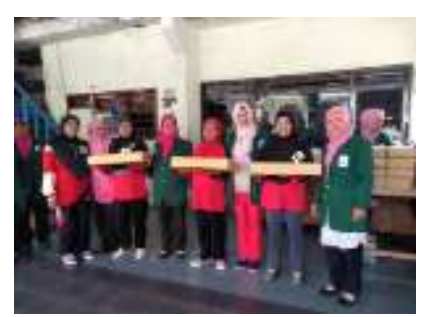

(c)

Gambar 6. Kegiatan Posyandu Lansia Sakura

\section{- Tanaman Toga}

UKBM (Upaya Kesehatan Bersumberdaya Manusia) adalah salah satu wujud nyata peran serta masyarakat dalam pembangunan kesehatan. Kondisi ini ternyata mampu memicu munculnya berbagai bentuk UKBM, salah satunya adalah TOGA (Tanaman Obat Keluarga). Tanaman obat keluarga disebut demikian karena Toga adalah singkatan dari tanaman obat yang berkhasiat sebagai obat dalam rangka memenuhi keperluan keluarga akan obat-obatan. Kebun tanaman obat atau bahan obat dan selanjutnya dapat disalurkan kepada masyarakat, khususnya obat yang berasal dari tumbuh-tumbuhan.. Keberadaan tanaman obat dilingkungan rumah sangat penting, terutama bagi keluarga yang tidak memiliki akses mudah kepelayanan medis 
seperti klinik, puskesmas ataupun rumah sakit. Tanaman obat-obatan dapat ditanam dalam potpot atau dilahan sekitar rumah. Dengan memahami manfaat dan khasiat dan jenis tanaman tertentu, tanaman obat menjadi pilihan keluarga dalam memilih obat alami yang aman (Siska Mayang Sari, Ennimay, \& Tengku, 2019).

Pemanfaatan TOGA; untuk memenuhi keperluan alam bagi kehidupan, termasuk keperluan untuk mengatasi masalah-masalah kesehatan secra tradisional (obat). Kenyataan menunjukkan bahwa obat yang berasal dari sumber bahan alami khususnya tanaman telah memperlihatkan peranannya dalam penyelanggaraan upaya-upaya kesehatan masyarakat. Pemanfaatan TOGA yang digunakan untuk pengobatan gangguan kesehatan keluarga menurut gejala umum adalah: Demam panas, Batuk, Sakit perut, dan Gatal-gatal.

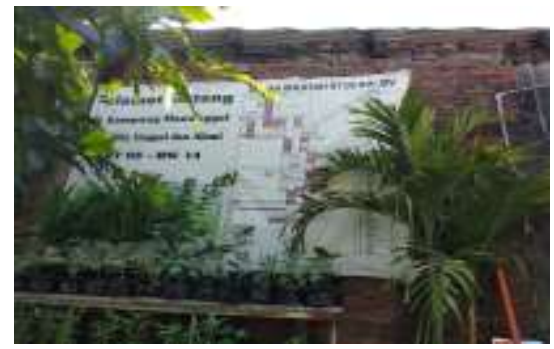

Gambar 7. Tanaman Toga yang ditanam oleh warga

\section{- Pembelajaran Lingkungan Hijau}

Pembelajaran tentang lingkungan hijau pada masyarakat khususnya pada anak - anak adalah yang paling utama karena dengan mengajarkannya tentang lingkungan hijau dan tanaman maka mereka akan sadar betapa pentingnya tanaman bagi manusia dan lingkungan mereka agar tetap sejuk dan indah dan memberi sisi postif bagi kesehatan. Pada RW 14, RT 03 mendidik anak - anak tentang lingkungan menggunakan gambar mural tentang menjaga lingkungan dan tanaman

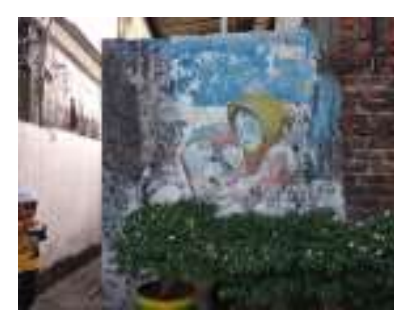

(a)

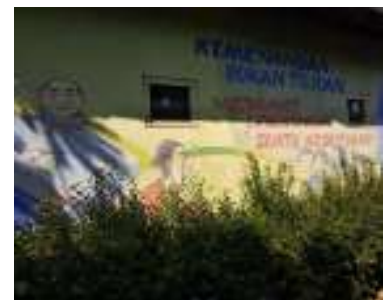

(b)

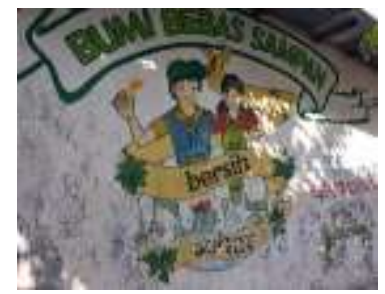

(c)

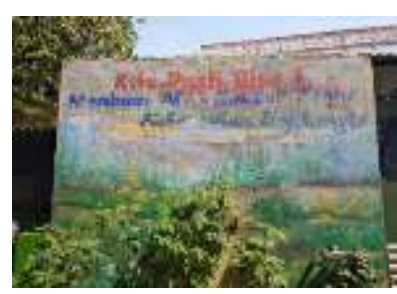

(d)

Gambar 8. (a) Mural Siramilah Tanaman (b) Mural merawat lingkungan suatu kebutuhan (c) Mural Bumi Bebas Sampah (d) Mural tentang kebersihan lingkungan

\section{- Kampung Kreatif}

Dimana permasalahan lingkungan khususnya sampah saat ini sudah sangat mengkhawatirkan bagi kelangsungan hidup kita. Selain itu, Berdasarkan data dari Direktorat Pengelolaan Sampah Kementerian Lingkungan Hidup dan Kehutanan (KLHK) produksi sampah nasional mencapai sekitar 65,8 juta ton pertahunnya di mana 16 persennya adalah sampah plastik. Dengan jumlah yang luar biasa itusampah tentunya menjadi ancaman yang sangat nyata bagi bangsa Indonesia. Pada dasarnya jenis sampah ada dua jenis yaitu: sampah organic dan anorganik, dimana sampah yang dapat didaur ulang adalah jenis sampah anorganik karena bukan dari makhluk hidup. sampah anorganik memerlukan waktu yang lama atau bahkan tidak dapat terdegradasi secara alami. Contoh sampah anorganik seperti: styrofoam, plastik, kaleng, dan bahan gelas atau beling (Marliani, 2015; Purwaningrum, 2016).

Strategi kreatif atau ide kreatif merupakan solusi permasalahan yang hadir atas desakan kebutuhan dasar manusia. Pada kasus pembentukan kampung kreatif, kondisi awal lingkungan permukiman yang tidak sesuai harapan menjadi suatu latar belakang yang memotivasi warga untuk mengambil tindakan dalam wujud ide atau strategi kreatif sebagai solusi permasalahan lingkungan tersebut. Hal ini dilakukan dengan mengembangkan kreatifitas warga yang meliputi 
Ruang Ekspresi (Kelompok Rebana Putri), Bank Sampah, Daur Ulang dan Hidroponik. Itu semua merupakan hasil dari UMKM untuk menetapkan identitas diri nya di persaingan dunia bisnis karena adanya keterbatasan kemampuan. Perkembangan di bidang teknologi informasi adalah salah satu faktor yang mempengaruhi peningkatan persaingan bisnis pada pasar regional maupun global. Dengan adanya faktor perkembangan teknologi informasi, produsen diharapkan mampu menawarkan dan menghasilkan produk yang memiliki keunikan tinggi dan inovatif pada pasarnya (Raden, 2019).

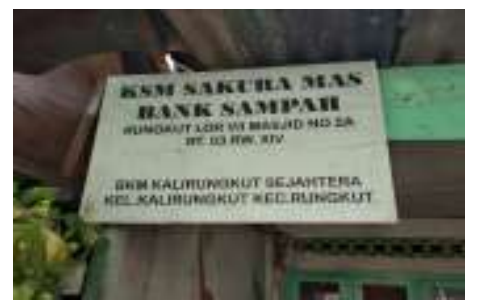

(a)

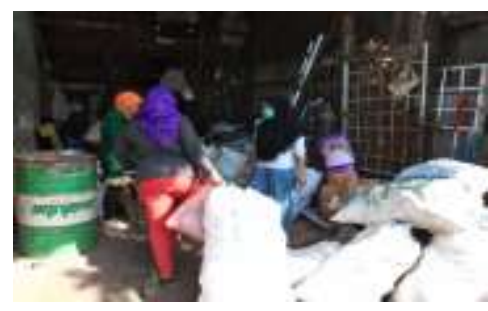

(b)

Gambar 9. Bank Sampah (a) Tempat Bank Sampah (b) Kegiatan yang dilakukan warga

Disamping kratifitas dalam Bank Sampah, warga juga mempunyai sentra untuk mewadahi kreatif dan inovatifnya yaitu: Wadah untuk kreatifitas warga mempunyai secretariat usaha bersama dan akan di pasarkan atau di stokkan pada pasar PGS (pasar grosir surabaya).

Pada umumnya UMKM di Indonesia terkendala pada permasalahan utama yang dihadapi oleh UMKM adalah permodalan. Keterbatasan permodalan membuat mereka melibatkan pemilik modal besar yang memperkenalkan sistem pembayaran dengan cara tradisonal dengan "Bon putih" dan disamping itu kalahnya persaingan dengan produk - produk yang memiliki brand. Oleh sebab itu tiap daerah harus memiliki potensi peluang dibidang produk unggulnya, sehingga dapat menghadapi kompetitif pasar bebas ASEAN Economic Community (AEC) (Ariani \& Utomo, 2017; Nurzamzami \& Siregar, 2016)

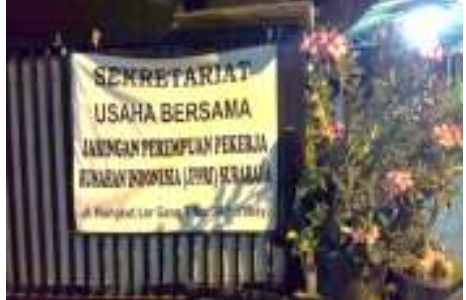

(a)

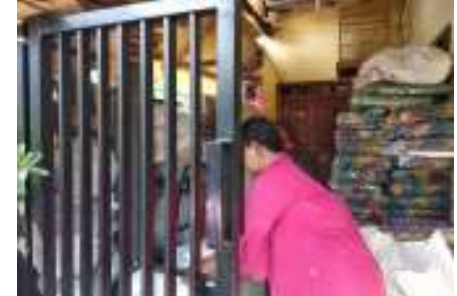

(b)

Gambar 10. (a) Wadah untuk kreatifitas warga mempunyai secretariat usaha bersama (b) Industri Kecil Warga Dibidang Pembuatan Keset

\section{- Kampung Aman}

Kampung aman pada RW 14 terletak RT 01 dan RT 03 dimana area kampung tersebut memiliki lalu lintas yang berguna untuk keselamatan warga sekitar terutama untuk anak - anak.

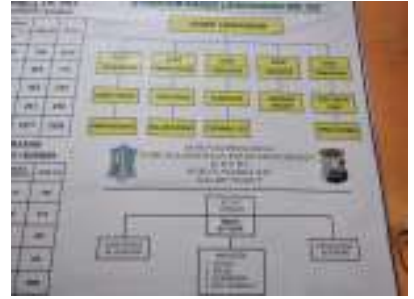

(a)

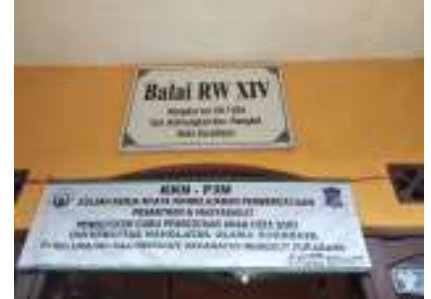

(b)

Gambar 11. Kampung aman (a) Susunan struktur organisasi sie keamanan RW 14 (b) Balai RW 14 


\section{KESIMPULAN}

Kesimpulan dari kegiatan pengabdian masyarakat ini adalah terciptanya Kampung Pendidikan ini bertujuan untuk menciptakan lingkungan daerah tinggal (kampung) yang edukatif, aman, nyaman, ramah, sehat, kreatif dan literat bagi proses tumbuh kembang anak dalam dukungan masyarakat yang menjamin pemenuhan hak anak dan mengupayakan perlindungan anak secara optimal.

\section{UCAPAN TERIMA KASIH}

Penulis mengucapkan terima kasih kepada Lambaga Pengabdian dan Penelitian Sekolah Tinggi Ilmu Ekonomi Indonesia (STIESIA) Surabaya yang telah memberi dukungan financial terhadap pengabdian ini.

\section{DAFTAR PUSTAKA}

Almatsier. (2011). Jakarta : Penerbit PT Gramedia Pustaka Utama. Baliwati. In Prinsip Dasar Ilmu Gizi. Jakarta.

Ariani, A., \& Utomo, M. N. (2017). Kajian Strategi Pengembangan Usaha Mikro Kecil Dan Menengah (Umkm) Di Kota Tarakan. Jurnal Organisasi Dan Manajemen, 13(2), 99-118. https://doi.org/10.33830/jom.v13i2.55.2017

Arisanti, I. (2020). Pendampingan Kemandirian TPA Az-Zahra Berbasis Pemasaran Sosial. Dinamisia : Jurnal Pengabdian Kepada Masyarakat. https://doi.org/10.31849/dinamisia.v3i2.3390

Hanafi, M. (2008). Konsep Dasar dan Perkembangan Teori Manajemen. Managemen.

Marliani, N. (2015). Pemanfaatan Limbah Rumah Tangga (Sampah Anorganik) Sebagai Bentuk Implementasi dari Pendidikan Lingkungan Hidup. Formatif: Jurnal Ilmiah Pendidikan MIPA, 4(2), 124-132. https://doi.org/10.30998/formatif.v4i2.146

Ningsih, F. G., \& Jonyanis. (2014). Perilaku hidup bersih dan sehat dalam rumah tangga (PHBS) masyarakat, Desa Gunung Kesiangan, Kec Benai, Kab Kuantan. Jom FISIP, 1(2).

Nurzamzami, A., \& Siregar, E. H. (2016). Peningkatan Daya Saing UMKM Alas Kaki di Kecamatan Ciomas, Kabupaten Bogor dan Implikasinya terhadap Strategi Pemasaran. Jurnal Manajemen Dan Organisasi, 5(1), 15. https://doi.org/10.29244/jmo.v5i1.12127

Permata Sakti, I. (2017). Implementasi Program Gerakan Desa Sehat Dan Cerdas (Gdsc) Di Desa Bulu Kecamatan Balen Kabupaten Bojonegoro (Studi Pada Parameter Sehat Indikator Angka Kematian Ibu Dan Angka Kematian Bayi). Publika, 5(3), 1-8.

Phillips, D., Burwood, S., Dunford, H., \& Maley, A. (2000). Projects with Young Learners. _Imp_001_N.

Prasanti, D., \& Fitriani, D. R. (2018). Pembentukan Karakter Anak Usia Dini: Keluarga, Sekolah, Dan Komunitas? (Studi Kualitatif tentang Pembentukan Karakter Anak Usia Dini Melalui Keluarga, Sekolah, dan Komunitas). Jurnal Obsesi : Jurnal Pendidikan Anak Usia Dini, 2(1), 13. https://doi.org/10.31004/obsesi.v2i1.2

Purwaningrum, P. (2016). Upaya Mengurangi Timbulan Sampah Plastik di Lingkungan. Indonesian Journal of Urban And Environmental Technology. https://doi.org/10.25105/urbanenvirotech.v8i2.1421

Raden, A. Z. M. (2019). Kerajinan Wayang Golek sebagai Produk Unggulan Daerah untuk Pemberdayaan Ekonomi Desa Tegalwaru. Dinamisia : Jurnal Pengabdian Kepada Masyarakat, 3(2), 180-188. https://doi.org/10.31849/dinamisia.v3i2.3140

Santrock, J. W. (2011). Perkembangan anak edisi 7 jilid 2. Terjemahan: Sarah Genis B) Jakarta: Erlangga.

Siska Mayang Sari, Ennimay, \& Tengku, A. R. (2019). Pemanfaatan Tanaman Obat Keluarga (TOGA) Pada Masyarakat. Dinamisia: Jurnal Pengabdian Kepada Masyarakat. https://doi.org/10.31849/dinamisia.v3i2.2833

Supriasa. (2012). Penilaian Status Gizi Edisi Revisi. In Penerbit Buku Kedokteran: EGC. 